\title{
The Futures Market for Farm Commodities - What It Can Mean to Farmers
}

\author{
NEIL A. STEVENS
}

\begin{abstract}
HE VALUE of all crops and livestock sold by farmers in 1973 totaled $\$ 88.6$ billion. Farm production expenses totaled $\$ 64.7$ billion or about 75 percent of total cash receipts. A considerable part of these outlays are committed to the production process six to eight months prior to marketing. During the period between the initial expenditures and the marketing of the product, changing price relationships between farm products and farm inputs result in considerable risk to the farm operator. Since production plans are made on the basis of price relationships during the planning stages, changes in such relationships can result in either "windfall returns" or substantial losses. Farmers may find in the futures market a means of reducing such risks.
\end{abstract}

Price risks in agriculture are larger than in most other industries. Historically, agricultural prices have fluctuated more widely than nonagricultural prices. For instance, prices received by farmers changed, on average, almost 10 percent per year since 1920 , more than double the average yearly fluctuation in wholesale industrial prices. In addition, prices paid by farmers and prices received by farmers have on occasion moved in opposite directions. On a yearly basis this has occurred ten times since 1920 .

One source of price fluctuations in agriculture is the nature of the demand for farm products. The quantity of food demanded is generally price inelastic - that is, the amount that people consume is relatively unresponsive to changes in price. Thus, small changes in the supply of farm products, resulting from adverse weather conditions for example, can lead to considerable price movement. In addition, shifts in demand stemming from general business fluctuations or changing export demands car have substantial effects on price. Traditionally, producers have bome most of the risk resulting from price fluctuations. However, in recent years such risks have been reduced somewhat by Government price support and production control programs.

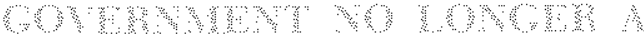 MAMR MGKMEARE}

Farm legislation of the past forty years has been designed to reduce the variation in farm prices and incomes for producers of major crops such as wheat, cotton, tobacco, and corn. Among the most important of the Government agricultural stabilization activities were the Commodity Credit Corporation operations which, in effect, set minimum prices for several farm commodities through the use of non-recourse loans to farmers on stored crops. Government inventories of some crops became quite large in years when production exceeded the amount demanded at the given loan rate. In these years farmers did not pay off the loans, but let the Government keep the commodity. The Government inventories were subsequently reduced through subsidized export sales or through sales in the domestic market in years when production was less than average. Government controls on the acreages that could be planted to various crops and limitations on total crop plantings have 
likewise tended to reduce the variation of farm output and prices. Even though Government programs can at times add to price instability via changes in farm legislation and changed administrative policies, the Government has nevertheless been a major price risk taker for a number of leading farm commodities.

Farm legislation passed in 1973 may result in less Government intervention in agricultural production and markets for farm products. Although price supports were retained, the support levels were set low enough relative to prevailing prices to allow sizable price fuctuations to occur. With the new legislation, farmers are now largely free to decide on the basis of economic forces the number of acres to plant, and farm product prices can generally seek the level at which the entire farm output clears the market. With the price mechanism free to respond to the various sources of fluctuations in farm output and changing demand for farm commodities, farmers are in the position of bearing greater risks than heretofore unless they take risk-reducing actions.

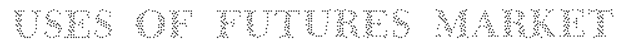 BY}

The farmer may find the futures market useful in reducing risks from changing relationships between the prices of farm inputs and prices on most major farm commodities. ${ }^{1}$ This market provides a means for making contracts for the delivery of commodities at a specified price at some future date. ${ }^{2}$ The use of the futures market by farmers generally involves selling a futures contract sometime during the crop or livestock production period, and purchasing a futures contract to offset the earlier futures sale when the product is marketed. For example, if at the time production is undertaken a certain return or profit is foreseen at current relative prices, that profit can be protected from risks of price changes by contracting to sell in the futures market the expected output at a specified price. Thus, the expected output may be sold at a specified price at the same time that resources are

1Futures contracts discussed in this article refer to those traded on formally organized exchanges. On the other hand, forward contracts, such as in contract farming, are made on a negotiated basis with terms agreed upon between producer and processor. Forward contracts can also be used by farmers to sell their expected output and reduce risk.

${ }^{2}$ For further details see Amen A. Alchian and William R. Allen, University Economics, 3rd ed. (Betmont, Califormia: Wadworth Publishing Company, Inc, 1972), pp. 163-67 and Thomas A. Hieronymus, Economics of Futures Trading for Commercial and Personal Profit (New York; Commodity Research Bureau, Inc, 1971). committed to the production process. ${ }^{3}$ If, for a particular commodity, a profitable price is not available at the beginning of the production period, the farmer can alter his plans. Otherwise, he is speculating on a change in price relationships or is willing to accept a lower rate of return for his resources than available in other lines of activity.

The strategy selected by the farmer for futures market operations will likely depend on several factors including the size of operation, stability of production, financial backing, and aversion to risks. A prerequisite for hedging investments in the production of farm products is an expected level of production large enough so that trading can be made in quantities specified in a futures contract. Thus the number of units in a futures contract reduces the ability of small farmers to hedge successfully, For example, trading units for major farm commodities generally consist of 5,000 bushels for corn, oats, soybeans, and wheat; 40,000 lbs. for live cattle; 30,000 Ibs. for live hogs; and $50,000 \mathrm{lbs}$. for cotton. ${ }^{*}$ The trend toward larger and more specialized farms, however, has increased the number of farmers who can take advantage of the futures market. Also a farmers' cooperative could be used by small farmers to assemble futures trading units.

The farmer's confidence in his ability to produce a given output has an impact on his futures trading strategy. For instance, a farmer who has a high degree of confidence in his output level may hedge all of his produce, whereas a producer with less confidence can hedge only a portion of his crop.

The desire for income stability stemming from a farmer's financial position may also influence his futures trading strategy. One who is heavily in debt may, through futures sales, afford himself some protection on his equity from disastrous price declines. At the time that the debt is contracted for agricultural production, the prospective crop or livestock out-

\footnotetext{
3This procedure is analogous to hedgtng. In the purest sense, hedging can be defined as taking an opposite position in the futures market from an actual position in the cash market, that is, buy in one and sell in the other. This definition applies most aptly to the hedging activities of grain dealers and grain elevator operators. Hedging can be more broadly defined to include futures operations of farmers when taking a position in the futzres market opposite to the expected position in the cash market. A full hedge implies taking an equal but opposite position in the two markets.

1The Micl America Commodity Exchange in Chicago, a rela tively small exchange, trades com, oats, soybean, and wheat in 1,000 bushel contracts and live hogs in 15,000 lb. contracts.
} 
put can be sold in the futures market, and the risk of a price decline can be avoided.

Attitude toward risk is also a factor determining futures trading. Two farmers with identical operations and financial positions may have different risk preferences. One may be willing to forego a known price at the time of planting for the possibility of greater profits later, while the other may be unwilling to assume the risk.

\section{Soll a Crop Whate Crowne}

Before the futures market developed, the farmer had little choice but to market his crops at harvest time or store them for later marketing. Now, however, assuming a profitable price is available, the farmer may be assured of a given profit per unit by selling contracts for the delivery of his expected harvest at a future date.

Suppose, for example, a wheat producer can profitably produce at least 10,000 bushels of wheat if, at the time of planting, he is assured of a price of $\$ 4.50$ per bushel. He expects to harvest his crop in late fune, and notices that the present futures price of July wheat is $\$ 4.50$ per bushel. To assure himself of this price he decides to sell 2 contracts of wheat of 5,000 bushels each (see Illustration I). Assume that in June when he harvests and markets his crop, the cash price of wheat has fallen to $\$ 4.25$ per bushel. Since futures and cash prices converge near the contract expiration date, the futures price will also be near $\$ 4.25$ per bushel. At the same time the producer sells his crop in the cash market for $\$ 4.25$ per bushel, he executes a buy order in the futures market for the same price, thus cancelling his earlier July contract committing him to delivery in July. ${ }^{5}$ He realizes a net gain of $\$ 0.25$ per bushel on his futures transactions while the cash market value of wheat was $\$ 0.25$ per bushel less than the price upon which he based his planting plans. Excluding the brokerage commissions, ${ }^{6}$ the net result of the three transactions (the cash sale and the two futures contracts) is that the farmer received the $\$ 4.50$ per bushel he anticipated (see Illustration I).

${ }^{5}$ Contracts can be automatically cancelled by an equal and opposite transaction. All transactions are monitored by a clearing corporation associated with the exchanges which reconciles all buy and sell orders at the end of each day. Only a very small percentage of futures contracts are fulfilled by actual delivery of the commodity.

Gurrently, the prevailing brokerage fee for a trading round of futures contracts (buy and sell) is $\$ 30$ for com, oats, soybeans, and wheat; $\$ 40$ for live cattle; and $\$ 35$ for live hogs. This fee is paid at the time the contract is cancelled.

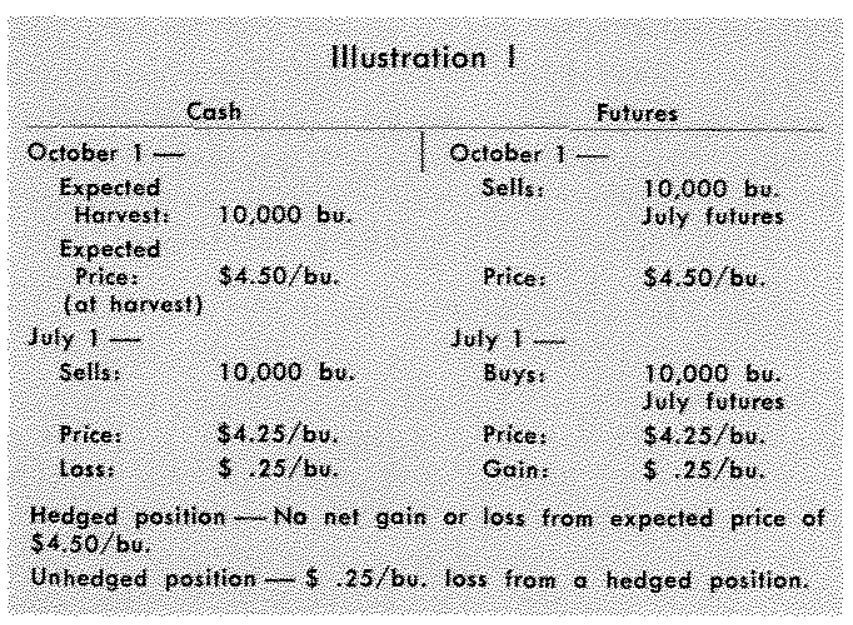

A farmer does not necessarily gain from a hedged as compared to an unhedged position. If the cash price increases during the production season, as in Illustration II, the farmer is worse off than if he had not hedged. The important point is that the farmer has, within fairly narrow limits, protected himself from downside price risk by hedging at the time of planting his crop.

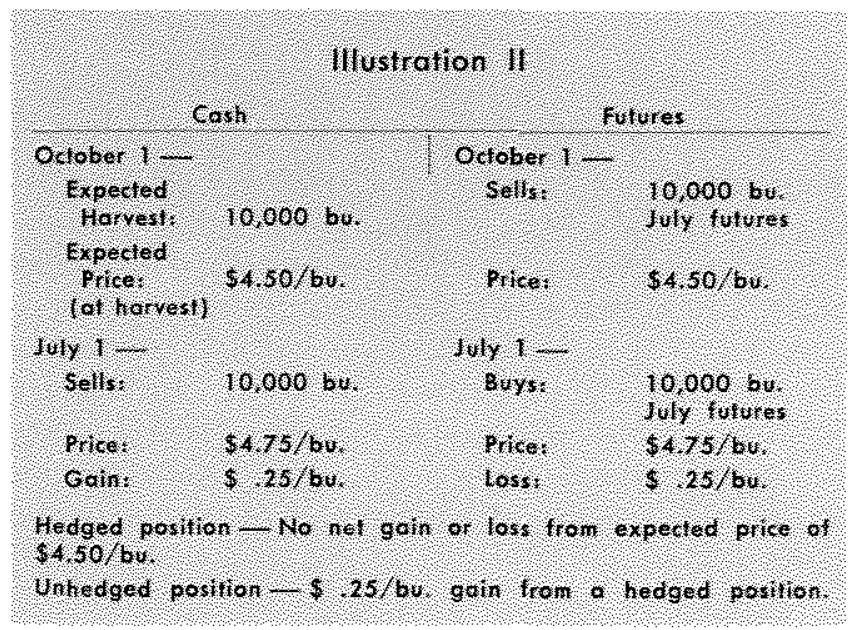

The producer who is uncertain of his output, but values highly a given price for at least part of his crop, may use the proportion of production expenses to expected receipts in deciding the amount of his crop to cover from price declines by futures trading. For example, if current operating expenses are 50 percent of expected receipts, an arbitrary rule of selling 50 percent of the expected crop forward provides some assurance of, at least, covering such expenses. This strategy is especially applicable to crops financed on borrowed money.

Large producers who have considerable uncertainty about their output and who wish to stabilize income may execute futures transactions on a regular basis 
over the growing season. For instance, if a large wheat producer expects an output of 40,000 bushels, and has a growing season of eight months, he can sell forward one-eighth of his expected crop each month. This strategy avoids locking-in any one price, say at the time of planting, and enables the farmer to receive an average price for his commodity. It also allows him to adjust expectations of crop yields by altering futures trading in the latter months of the production season, thereby reducing risk of over or under commitment in the futures market.

The futures market also can sometimes be used to gain storage income on existing storage facilities, without bearing price risks, by selling the stored commodity forward. A farmer may already have invested in storage facilities in order to take advantage of seasonal price movements or other speculative possibilities. If, for example, a farmer stores 10,000 bushels of wheat at harvest time, but anticipates adverse price changes, he can sell 2 contracts of May futures for say $\$ 4.50$ a bushel. For illustration, suppose the cash price of wheat is $\$ 4.30$ a bushel, the difference between the cash and futures prices being the implicit return for storage of the commodity until May. In May the cash price may have fallen to $\$ 4.00$ a bushel, but since the cash and futures prices tend to converge in the expiration month, the futures prices will also be around $\$ 4.00$ a bushel. In May the farmer cancels his futures contract by buying May futures and selling in the cash market the stored commodity. Illustration III summarizes the transactions in the two markets. The farmer gains $\$ 0.50$ a bushel from the two futures transactions, but loses $\$ 0.30$ a bushel in the eash market, achieving a net gain of $\$ 0.20$ a bushel, the return for storage. In practice, using the procedure described above to lock-in a return to storage may be difficult to carry out, especially when commodity prices are fluctuating widely.

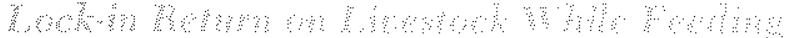

A livestock feeder has opportunities similar to those of the crop producer for assuring himself a given return. He commits substantial resources to his operation when calves are bought to finish for slaughter. The value of the feeder calves and the early feed purchases may total 50 percent or more of the final sales of fat cattle. Such operations are often run on a small equity and the risks of loss over the relatively long feeding period are quite large. Hence, it is often desirable to both the feeding operator and his creditors to protect his equity position from the possibility of substantial downside price risks. This can be done

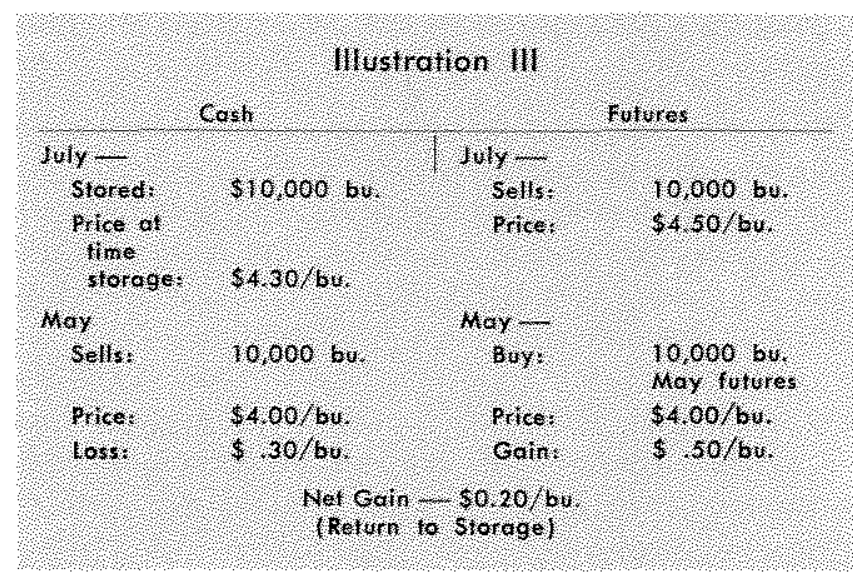

at the time cattle are purchased by selling live cattle futures in the expected month in which newly-purchased cattle will be marketed.

For example, assume that a cattle feeder purchases 200 feeder calves averaging $500 \mathrm{lb}$. per head for a price of $\$ 40$ per hundredweight - an outlay of $\$ 40,000$. On the basis of past experience, $500 \mathrm{lbs}$. of weight can be put on each animal in six months at a feed cost of $\$ 44$ per hundredweight. The outlay for calves and feed will average $\$ 42$ per hundredweight for the 1,000 lb. cattle, and will total $\$ 84,000$ for the 200 animals. Suppose that at the time of purchase the price of live cattle futures for delivery six months hence were $\$ 45$ per hundredweight, or $\$ 90,000$ for the 200 head of $1,000 \mathrm{lb}$. cattle. If at the time of purchasing the cattle, he also sells 5 contracts in the futures markets to cover the expected production, then reversing his futures position when the finished cattle re sold in the cash market, the farmer can be assured of a $\$ 30$ per head return to labor and capital, or $\$ 6,000$, profit, on the 200 head.

As in the case of the crop farmer, numerous other variations on the use of futures markets are possible. The feeder may prefer to carry his own price risks at the time he buys the feeder animals. Subsequently, however, during the feeding process he may see a futures price that will assure a profit and decide to forego further risk. He could then sell live cattle forward and lock-in a given profit or a given loss level, assuming that his anticipated feeding efficiency level is realized.

Livestock feeders are not only subject to changing prices of live cattle, but also to changing prices of feed inputs during the production period, since changes in feed costs often do not immediately affect live beef prices. If storage facilities are limited, the feeder can still lock-in his feed cost at the beginning 
of the operation by use of futures contracts for feed grains.

Suppose that in our previous example the cattle feeder requires 10,000 bushels of com to finish the cattle for marketing, but has storage facilities for only 5,000 bushels. He can lock-in the price of com at the time of buying the feeder calves by buying com forward. If the cash corn price is $\$ 3.50$ a bushel, he can buy a contract of corn (5,000 bushels) for, say, $\$ 3.70$ a bushel (cash price plus storage cost). Suppose that as the corn is used for feeding purposes, the cash price has risen to $\$ 3.60$ a bushel, and the futures price has risen only to $\$ 3.75$ a bushel. The spread between cash and the future price has narrowed since storage costs are taken into account. The feeder now buys corn for $\$ 3.60$ a bushel and sells his futures for $\$ 3.75$. The net transaction saved him $\$ 0.05$ a bushel for corn, and he in effect paid $\$ 0.05$ a bushel for storage during the period. These types of futures transactions add to the options available to the feeder. They may be used to assure a certain cash price for fed animals, to take advantage of current feed prices, or to avoid investment in storage facilities.

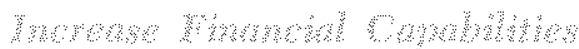

The futures market can also aid in increasing financial capabilities. For example, a cattle feeder whose operations are hedged through futures sales has the added insurance that the loan will be repaid. With this additional safety feature lenders are likely to provide larger loans and/or easier terms. With the larger loan, operations can be expanded and the farmer's equity can be more highly leveraged with a minimum of risk to both the lender and the borrower.

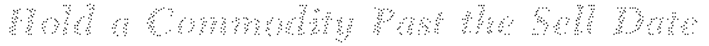

In order to give the full realm of uses of the futures market, it should be noted that farmers can also increase their speculative position through futures contracts. The futures market is often a more convenient way of speculating than holding the commodity itself. A farmer who wishes to speculate on a commodity, but who does not want to go to the inconvenience of storing the commodity or has no storage facilities available, can always take a "long" position on the commodity by buying a futures contract. By selling his crop at the time of harvest in the cash market and simultaneously buying back a like amount of the same commodity in the futures market, he will, in effect, gain from any price increases that may occur. In doing this, of course, the farmer is speculating that the price will rise in the near future.

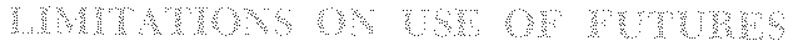

Using the futures market does not eliminate the necessity of the decision of when to buy or sell. Rather, it increases one's marketing options and allows equity to be more highly leveraged. The grain producer, for example, can effectively sell his crop at the time of planting, he can sell anytime during the growing process if he considers the price attractive, or he can delay a commitment to a price by speculating past the harvest date. In any case, he must make the decision as to when to sell. Futures trading simply gives him the option of selling at any time he desires, thus shifting the risk to others who wish to assume the risk of price decline with the expectation of profits.

Secondly, a risk of not carrying out a successful hedge - that is, not obtaining the targeted price - is also present. In theory, the spread between cash and futures prices is accounted for by the cost of storage, and as the contract date moves closer to expiration the spread between the cash and futures price narrows. Sometimes events can interfere with this usual working of the markets; transportation problems, like a shortage of box cars, strikes, and Government price controls, are such examples.

Prices vary, not only over time, but also over geographical area. Since the farmer usually plans to deliver his commodity at his local cash market, he must also be knowledgeable about the spread between the price in his local cash market and the futures market. Sometimes, prices in local markets do not move in concert with the larger markets, resulting in possible gains or losses to the hedger.

Third, hedging fixes only the sale price per unit, not total returns to production. In agriculture, production is subject to considerable output variation, and thus expected production is not always realized. If a farmer hedges all of an anticipated crop, but the expected level of production is not realized, he bears the price risk on the excess amount contracted. In this case futures contracts can be purchased or sold to cover the difference if large enough.

Fourth, a farmer who, over a period of several years, locks-in the available price by hedging during the production season is not likely to realize major gains or losses as compared to a farmer who is willing and able to carry such risks himself. Hedging during the production process helps to eliminate the big losses which could cause financial hardship or even bankruptcy. However, as we saw earlier in Illustration II, hedging may also eliminate big gains in years in 
which wnexpected prioe increases occur near the marketing dates.

A farmer who can readily adjust his operations so as to increase his output and lock-in a given price at profitable levels of production, could possibly increase his average return. A hog producer, for example, may be able to increase his return through futures trading by expanding his production when a greaterthan-average return is expected. Crop farming may likewise lend itself to this type of adjustment through shifts from one crop to another or changes in inputs. Most of such adjustments, however, may be practical only on a moderate scale, as typical farming operations are generally run on a continuous basis.

Fifth, futures trading involves costs. These costs include the commissions on the futures contracts, the foregone interest on the margin, or interest charges if the margin is borrowed. ${ }^{\top}$ These costs, however, can

TThe initial margin requirement (amount of cash required of the buyer or seller at the time a contract is initiated with a brokerage firm) may vary from 5 to 20 percent of the total market value of the contract. The maintenance margin (the minimum amount of equity the buyer or seller is required to bold with his brokerage firm) is ustally 60 to 85 percent of the initial margin. If sufficient adverse price movements occur, brokerage firms will require further cash to maintain the minimum or they will automatically reverse the position. For more often be offset by larger loans or more favorable terms that lending institutions will give when the commodities are protected from price risk via the futures market.

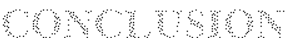

Risk must be borne by all businessmen, but farmers are especially subject to considerable price risk. Farmers have tried to protect themselves from fluctuations in prices and income via the political process, and considerable public resources have been devoted to the stabilization of agricultural prices. Now, however, the Government may be less active in the stabilization of agricultural prices.

Futures trading can be used by farmers to help insulate themselves from changing relationships between input and output prices during the production process. In a free-market environment for agricultural products it may behoove farmers to investigate the futures market and see what use it can be in their overall marketing plans. This is especially true of farmers who are heavily leveraged and thereby not in a position to absorb heavy losses,

details, see Hieronymus, Economics of Futures Trading, pp. 62-65.

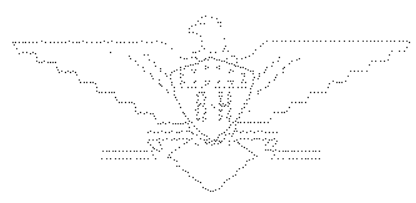

